\section{$\mathrm{Y}-12$}

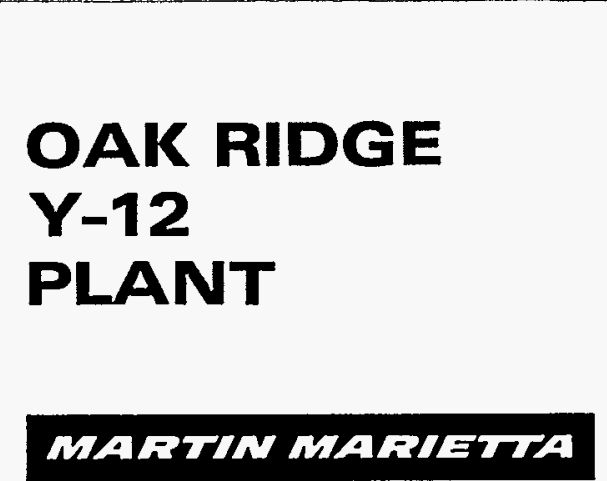

MANAGED BY

MARTIN MARIETTA ENERGY SYSTEMS, INC.

FOR THE UNITED STATES

DEPARTMENT OF ENERGY

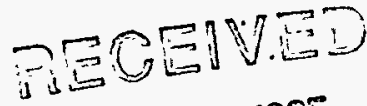

DEC 191933

(C) S.II

A TECHNICAL STUDY

of

TLD BETA CALIBRATION FACTOR

for

EXPOSURE TO DEPLETED URANIUM

J. C. Ashley

J. E. Turner

M. L. Souleyrette

R. S. Bogard

K. L. McMahan

June 1995

DISTRIBUTION OF THIS DOCUMENT IS UAULMTED TR 


\section{DISCLAIMER}

This report was prepared as an account of work sponsored by an agency of the United States Government. Neither the United States Government nor any agency thereof, nor any of their employees, makes any warranty, express or implied, or assumes any legal liability or responsibility for the accuracy, completeness, or usefulness of any information, apparatus, product, or process disclosed, or represents that its use would not infringe privately owned rights. Reference herein to any specific commercial product, process, or service by trade name, trademark, manufacturer, or otherwise, does not necessarily constitute or imply its endorsement, recommendation, or favoring by the United States Government or any agency thereof. The views and opinions of authors expressed herein do not necessarily state or reflect those of the United States Government or any agency thereof. 


\title{
A TECHNICAL STUDY OF TLD BETA CALIBRATION FACTOR FOR EXPOSURES TO DEPLETED URANIUM
}

\author{
J. C. Ashley and J. E. Turner \\ Health Sciences Research Division \\ Oak Ridge National Laboratory \\ Post Office Box 2008 \\ Oak Ridge, Tennessee 37831
}

M. L. Souleyrette and R. S. Bogard

Health, Safety, Environment, and Accountability Division

Y-12 Plant

Post Office Box 2009

Oak Ridge, Tennessee 37831

\author{
K. L. McMahan \\ Office of Radiation Protection \\ Oak Ridge National Laboratory \\ Post Office Box 2008 \\ Oak Ridge, Tennessee 37831
}

June 1995

\author{
Prepared by the \\ Oak Ridge Y-12 Plant \\ P. O. Box 2009, Oak Ridge, Tennessee 37831-8169 \\ managed by \\ LOCKHEED MARTIN ENERGY SYSTEMS, INC. \\ for the \\ U.S. DEPARTMENT OF ENERGY \\ under contract DE-AC05-84OR21400
}




\section{DISCLAIMIER}

Portions of this document may be illegible in electronic image products. Images are produced from the best available original document. 



\begin{abstract}
The beta calibration factor for converting light output (on reading a thermoluminescent dosimeter) to shallow dose equivalent has been re-examined through theoretical calculations and experimental measurements. The results support the previously determined value for contact with a depleted uranium slab but indicate that for many actual workplace situations, the contact value may be overly conservative.
\end{abstract}




\section{A TECHNICAL STUDY OF TLD BETA CALIBRATION FACTOR}

\section{FOR EXPOSURES TO DEPLETED URANIUM}

\section{INTRODUCTION}

This report describes a study undertaken to review and assess the beta calibration factor used for determining shallow dose equivalent for workers who handle depleted uranium (DU). The shallow dose equivalent, the dose equivalent at a nominal depth of $7 \mathrm{mg} / \mathrm{cm}^{2}$ in skin, is inferred from readings of the thermoluminescent dosimeters (TLDs) worn by the workers. The dose-equivalent algorithm for interpreting the readings offers the option of using either (1) an energy-dependent, point-source factor or (2) a single factor derived for the dosimeter in contact with a DU slab (DO86, MV90, USERS89, USERS91). The more conservative slab factor has been used as a default dose conversion factor for the Oak Ridge Y-12 Plant since the Centralized External Dosimetry System (CEDS) was implemented in 1989.

For this study, work areas and working conditions were surveyed and considered from the standpoint of geometries for "point-source" and "slab" calibration factors for beta shallow dose equivalent. A set of measurements was carried out with dosimeters both in contact with DU slabs and at a distance of $30 \mathrm{~cm}$ from each slab. The effects of slab areas of different sizes on the dosimeter response were measured. Relevant literature was surveyed and calculations performed, as reported below, to independently assess the appropriateness of the calibration factor used for exposure to DU under a variety of source/geometry conditions. The value for the slab calibration factor is supported by new measurements on DU slabs, i.e., the currently used factor is adequate, though perhaps too conservative in many instances. In principle, as the DU source dimensions decrease for a fixed TLD- 
source distance (or, for a given, finite source as the TLD-source distance increases), the calibration factor should approach that for a point source; the details of such a transition are not examined in this report.

\section{TLD SYSTEM AND CALIBRATION}

The Harshaw Model 8805 multi-element thermoluminescent dosimeter is described in detail elsewhere (MV90, USERS89, USERS91). It consists of a holder and a card with four LiF:Mg,Ti chips. Each chip is mounted with its own unique filtration to provide different absorption thicknesses as a basis for estimating deep and shallow dose equivalents. The light output from each chip is measured automatically in a TLD card reader in terms of a locally defined unit, $\mathrm{mR}^{*}$ (CE93). The dose-equivalent algorithm employs a decision tree, based on the relative responses of the different chips, to interpret the kind of exposure that occurred: i.e., primarily beta particles, beta particles plus low-energy or intermediate- and high-energy photons, photons only, and neutrons. The algorithm then provides values of dose equivalent from photons and beta particles and an estimate for neutron exposure; a separate dosimeter is used to determine neutron dose equivalent. Development of the algorithm is based on calibration measurements made with a variety of pure and mixed-field sources.

For beta particles, the calibration factors are based on experimental data obtained for ${ }^{90} \mathrm{Sr}{ }^{\rho 0} \mathrm{Y}$ and ${ }^{204} \mathrm{Tl}$ point sources and for a DU slab source in contact with the dosimeter (USERS89).

Given the net light output, $L_{3}\left(m R^{*}\right)$, from chip 3 on the TLD (the "shallow-dose chip") following exposure to a beta source, the shallow dose equivalent $H_{S}$ is calculated from the formula (MV90) 


$$
H_{S}(m r e m)=L_{3}(m R)^{*} / r_{S}^{\prime}(m R * / m r e m)
$$

where $r^{\prime}{ }_{S}$ is the shallow dose-equivalent response factor. Calibration of the TLDs for contact with a DU slab and at a distance of $30 \mathrm{~cm}$ from a ${ }^{90} \mathrm{Sr}{ }^{\circ 0} \mathrm{Y}$ or ${ }^{204} \mathrm{Tl}$ point source, and calibration of the TLD reader system, lead to numerical values for $r^{\prime}$. Details are given in the Appendix. For these beta sources, a given light output would yield, from Eq. (1),

DU slab: $\mathrm{H}_{S}$ (mrem) $=1.68 \mathrm{~L}_{3}\left(\mathrm{mR}^{*}\right)$

$$
{ }^{90} \mathrm{Sr} /{ }^{00} \mathrm{Y} \text { point: } \mathrm{H}_{\mathrm{S}}(\mathrm{mrem})=0.957 \mathrm{~L}_{3}\left(\mathrm{mR}^{*}\right)
$$

These values of $\mathrm{H}_{S} / \mathrm{L}_{3}$ are the maximum and minimum calibration factors used for beta shallow doseequivalent calculations based on calibration of the TLD/reader system. Calibration with the lowerenergy beta particles from a ${ }^{204} \mathrm{Tl}$ point source $\left(E_{\beta}{ }^{\max }=0.765 \mathrm{MeV}\right)$ gives an intermediate calibration factor of 1.38 .

A more sophisticated analysis, based on the light output from all four chips, is codified in a dose calculation algorithm (MV90), which accounts for photon contributions and variations in maximum beta-particle energies. It specifies corrections for nonlinearity in the case of very large doses ( $>1 \mathrm{~Gy})$ and for decreases in the TLD light output due to decay of metastable states in LiF at 
ambient temperatures ("fading"), based on the time between preparation and reading of the TLD. Equations (2a) and (2b) will be used for comparisons with calculations and experimental results in this study.

\section{SURVEY OF ROUTINE WORKER CONTACT WITH URANIUM AT Y-12}

Depleted uranium is responsible for the majority of shallow dose exposures at Y-12. Processing of DU ranges from the initial charge make-up and induction melting to the cleaning, machining, and quality-assurance testing of the final metal product. Intermediate operations include blast and ultrasonic cleaning, sawing, heating, rolling, and pressing.

In order to assess workplace geometry conditions at the Y-12 Plant, Health Physics personnel reviewed those areas in which workers had historically received the highest shallow dose equivalents. These areas are the H-1 Foundry, the 9201-5 Arc-Melt Facility, the 9204-4 Forming Area, a machine shop (represented by 9201-5N), and the Product Certification Groups of Y-12 Quality (Ultrasonic Testing, Mechanical Properties, Dimensional Inspection, and Radiography).

In the Foundry, Arc Melt Facility, Forming Area, and machine shops, workers handle both large and small pieces of depleted uranium metal. The workers are not typically in bodily contact with the material. Large parts are lifted with mechanical assistance, and the workers generally remain 2-3 feet away from the material. Smaller parts may be loaded by hand, but these are typically handled at arm's length. A worker is rarely in close contact (less than $30 \mathrm{~cm}$ ) with material for an extended period of time. 
The Ultrasonic Testing Group of Y-12 Quality has a workplace geometry similar to the areas described above. Large parts are loaded mechanically onto testing machines. Small parts may be loaded by hand. The operator may also adjust the parts at arm's length. After loading and adjusting, the operator steps away to a control center typically three feet away, where he remains for the majority of the time he is working with the material.

The Mechanical Properties Inspection Laboratory works with pieces of depleted and enriched uranium smaller than the dimensions of the dosimeter. The pieces are tested and photographed, with the worker generally at least $30 \mathrm{~cm}$ from the material.

The Dimensional Inspection Group checks dimensions of parts using both large machines (Dual Arm and Y-Z Machines) and hand-held instruments, such as calipers. While using the large machines, the geometry is nearly identical to that of the machine shops and Ultrasonic Inspection area. Inspection performed using hand-held instruments ("plate work") places a worker in intimate contact with the material. The exact nature of the work varies with the particular inspection performed, but the potential exists for a worker to be in close proximity (less than $30 \mathrm{~cm}$ ) to a large part for as much as four hours per shift. Plate work is performed on both depleted and enriched uranium parts.

Radiographers load parts onto radiography tables by hand and position and mark the parts for $\mathrm{x}$-ray inspection. A typical part will require taking seven exposures; the operator adjusts and marks the part after each exposure. While loading and adjusting, the radiographer may typically be within $30 \mathrm{~cm}$ of the part for a total time of 30 minutes per part.

Results of the workplace reviews revealed that two groups (Dimensional Inspection and Radiography) have workers for whom the slab geometry may be appropriate. Particular employees 
in these groups for whom the slab geometry should be used will be identified by the Dosimeter Distribution Center and will continue to have their dose equivalents calculated by using a slab beta calibration factor. For other than these two groups it appears that workers at the $\mathrm{Y}-12$ plant rarely, if ever, work with large pieces of uranium at distances less than $30 \mathrm{~cm}$.

Depleted uranium is the principal source of shallow dose equivalent at the Y-12 Plant. The contribution to shallow dose-equivalent rate from enriched uranium is considerably less than that from depleted uranium. Due to the much lower energy beta component from enriched uranium and its daughter products, workers would have to be in extremely close contact with enriched uranium to achieve a planar geometry. Typical operations with enriched uranium do not place workers in this close proximity.

Reviews of new and existing operations for radiological concerns are conducted by the Radiological Engineering Section of the Y-12 Health Physics Department in accordance with Procedures Y70-129 and Y50-66-HP-600 ("Radiological Control Surveillances"). Radiological engineers will provide information on irradiation geometry to the Dosimeter Distribution Center Supervisor to ensure that workers in slab geometry conditions are identified and their doseequivalents appropriately calculated.

\section{EXPERIMENTAL MEASUREMENTS WITH DU}

A series of experiments was carried out at the ORNL Radiation Standards and Calibration Laboratory to simulate exposure to DU slabs of various sizes. Harshaw Model 8805 TLDs were exposed in contact with, and $30 \mathrm{~cm}$ distant from, square DU slabs of dimensions 1,3 , and 5 feet on a side. The absorber thicknesses are shown in Fig. 1 for the contact measurements. The net light 
output from chip 3 per hour of exposure was evaluated. The results are summarized in Table I and supplemented by measurements on smaller DU sources from an earlier report (IR92). For most of these new measurements the TLDs were prepared, exposed, and read on a schedule to minimize fading. For the $5^{\prime} \times 5^{\prime}$ slab, a fading correction (MV90) corresponding to 34 days from preparation to reading was applied to obtain the $30 \mathrm{~cm}$ value for shown in the table. Further conditions on the measurements are given in the Table Notes. No supralinearity (MV90) corrections were required.

\section{FIG. 1. Absorbers and thicknesses encountered with TLD in contact with a DU slab.}

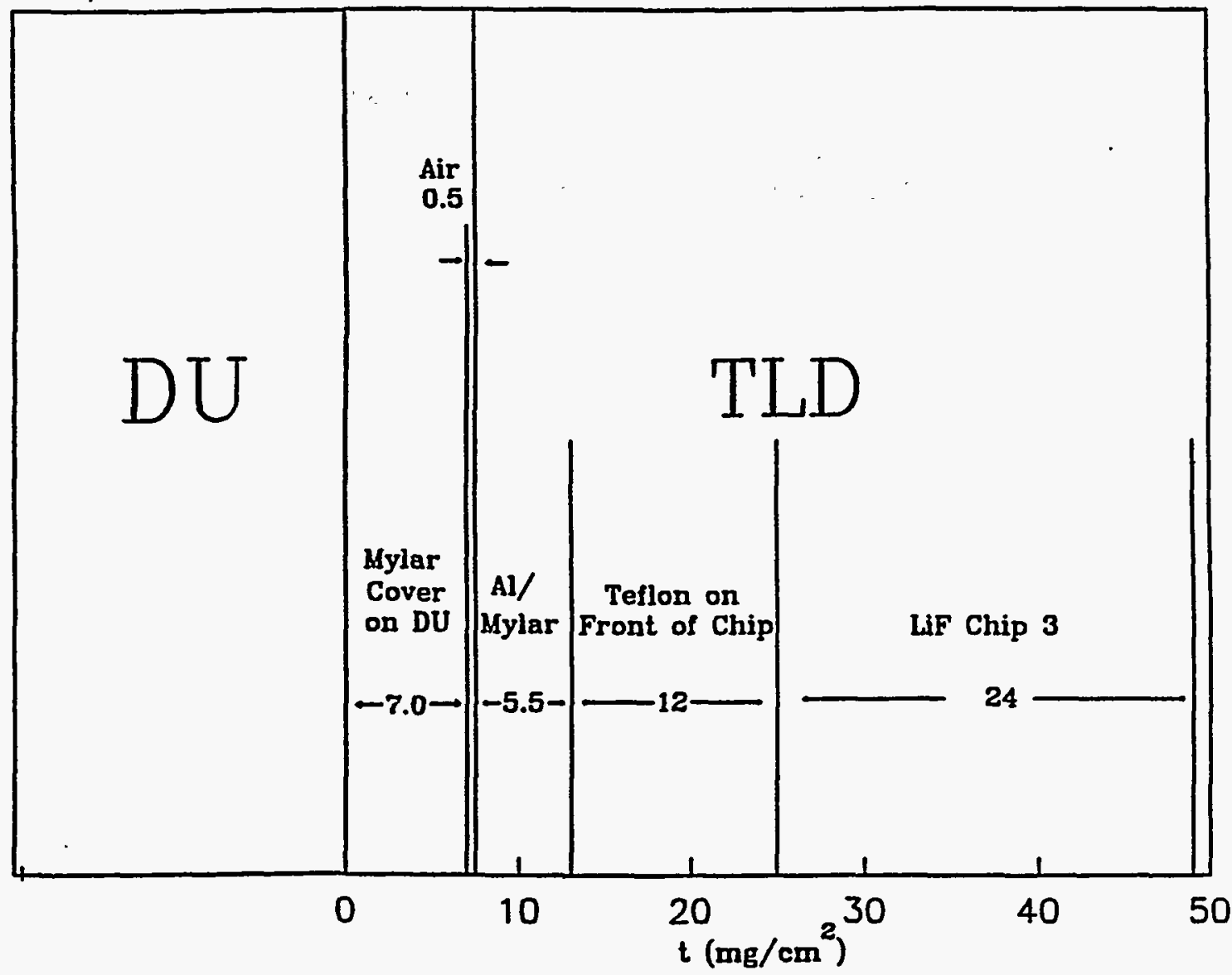




\section{TABLE I. TLDs Exposed to Various Configurations of DU}

\begin{tabular}{|c|c|c|c|c|c|}
\hline \multirow[b]{2}{*}{ Sample size } & \multicolumn{2}{|c|}{ Reference IR92 } & \multicolumn{3}{|c|}{ New Measurements } \\
\hline & $1.5^{n} \times 1.5^{n} \times 1.5^{n}$ & $5^{n} \times 5^{n} \times 0.3^{n}$ & $1^{\circ} \times 1^{\circ} \times 0.3^{n}$ & $3^{\prime} \times 3^{\prime} \times 0.3^{n}$ & $5^{\circ} \times 5^{-} \times 0.3^{n}$ \\
\hline Surface area facing TLD & $14.5 \mathrm{~cm}^{2}$ & $161 \mathrm{~cm}^{2}$ & $929 \mathrm{~cm}^{2}$ & $8.36 \times 10^{3} \mathrm{~cm}^{2}$ & $2.32 \times 10^{4} \mathrm{~cm}^{2}$ \\
\hline "Contact", $\mathbf{L}_{3}\left(\mathrm{mR}^{*} / \mathrm{h}\right)^{\mathrm{b}}$ & 106 & 138 & 124 & 124 & 124 \\
\hline $30 \mathrm{~cm}$ or $1 \mathrm{ft} ., \dot{L}_{3}\left(\mathrm{mR}^{*} / \mathrm{h}\right)^{\mathrm{b}}$ & 0.39 & 8.9 & 33.1 & 97.1 & 98.5 \\
\hline Reduction factor & 0.0037 & 0.064 & 0.27 & 0.78 & 0.79 \\
\hline
\end{tabular}

a. These measurements were made July - August 1993, by K. G. Sanders at the ORNL Radiation Standards and Calibration Laboratory. The "contact" measurement is an average for six TLDs on a $1^{\circ} \times 1^{\circ}$ DU slab, and is assumed to apply for the larger-sized arrays. The non-contact measurements were made at $30 \mathrm{~cm}$; each $\dot{L}_{3}$ value results from a four- or six-TLD average after background subtraction.

b. These are the average light output readings for chip 3 per hour of exposure, with the card in the standard holder, after exposure under the indicated conditions (with background subtracted).

As expected, the distance reduction factor for the light output from chip 3 decreases rapidly with decrease in size of the DU. For measurements made at a distance of $30 \mathrm{~cm}$, it is seen that the $3^{\prime} \times 3^{\prime}$ slab of DU is effectively infinite in lateral extent.

\section{RELEVANT LITERATURE AND CALCULATIONS}

The principal decay scheme for depleted uranium, showing particulate radiations and halflives, can be represented as follows:

$$
{ }_{92}^{238} \mathrm{U} \underset{4.5 \times 10^{9} \mathrm{y}}{\stackrel{\alpha}{\longrightarrow}}{ }_{90}^{234} \mathrm{Th} \underset{.24 .1 \mathrm{~d}}{\stackrel{\beta^{-}}{\longrightarrow}}{ }_{91}^{234 \mathrm{~m}} \mathrm{~Pa} \underset{1.17 \mathrm{~m}}{\stackrel{\beta^{-}}{\longrightarrow}}{ }_{92}^{234} \mathrm{U}
$$


The short-lived ${ }^{234} \mathrm{Th}$ and ${ }^{234 \mathrm{~m}} \mathrm{~Pa}$ are in secular equilibrium with ${ }^{238} \mathrm{U}$. For external dosimetry, the principal hazard arises from the energetic beta particles from ${ }^{234 \mathrm{~m}} \mathrm{~Pa}$, having a maximum beta-particle energy $\mathrm{E}_{\beta}^{\max }=2.29 \mathrm{MeV}$. For ${ }^{234} \mathrm{Th}, \mathrm{E}_{\beta}^{\max }=0.191 \mathrm{MeV}$. With an absorber of thickness $30-40$ $\mathrm{mg} / \mathrm{cm}^{2}$ (e.g., $30 \mathrm{~cm}$ air) between the DU and a detector, the dose will be due almost entirely to the beta particles emitted from the protactinium in the direction of the detector. These statements are consistent with results shown in Table II for dose-equivalent-rate factors as a function of depth in water for an infinite-plane source at a water-air interface (KE87). Only absorbed dose due to beta particles is included in the numbers shown. The absorbed dose due to beta particles from thorium

\section{TABLE II. Dose-Equivalent Rate Factors at Several Depths in Tissue for Thin Planar Sources (KE 87)}

\begin{tabular}{|c|c|c|c|c|c|}
\hline \multirow{2}{*}{ Nuclide } & \multirow{2}{*}{$\begin{array}{c}\mathrm{E}_{\beta}^{\max } \\
(\mathrm{MeV})\end{array}$} & $4 \mathrm{mg} / \mathrm{cm}^{2}$ & $7 \mathrm{mg} / \mathrm{cm}^{2}$ & $8 \mathrm{mg} / \mathrm{cm}^{2}$ & $40 \mathrm{mg} / \mathrm{cm}^{2}$ \\
\cline { 3 - 6 } & 2.27 & $2.4 \times 10^{-2}$ & $2.1 \times 10^{-2}$ & $2.0 \times 10^{-2}$ & $1.2 \times 10^{-2}$ \\
\hline${ }^{90} \mathrm{Y}$ & 2.29 & $2.4 \times 10^{-2}$ & $2.1 \times 10^{-2}$ & $2.0 \times 10^{-2}$ & $1.1 \times 10^{-2}$ \\
\hline${ }^{234 \mathrm{~m}} \mathrm{~Pa}$ & 0.191 & $9.5 \times 10^{-3}$ & $3.1 \times 10^{-3}$ & $2.2 \times 10^{-3}$ & $4.3 \times 10^{-7}$ \\
\hline${ }^{234} \mathrm{Th}$ & & & & & \\
\hline
\end{tabular}


is $\sim 15 \%$ of that from protactinium at $7 \mathrm{mg} / \mathrm{cm}^{2}$. Also included in Table II are values for ${ }^{90} \mathrm{Y}$. Yttrium and protactinium are seen to have essentially the same dose-equivalent-rate factors. Thus, for analyzing beta-particle doses, ${ }^{90} \mathrm{Y}$ appears to provide a useful approximation to DU. This close equivalence is important for the calculations to be discussed below.

\section{Absorber Material}

Materials with the same physical thicknesses can have very different behaviors as beta-particle absorbers. For two materials to have similar properties for beta-particle penetration, their atomic composition and hence mass stopping power must be similar. Since the stopping powers of skin (ICRU44) and liquid water (IRCU37) for electrons differ by less than $1 \%$ for $0.01 \leq \mathrm{E}_{\beta}(\mathrm{MeV}) \leq 3.0$, we assume they are equivalent absorbers and use "skin" or "water" interchangeably. To convert the thickness $t_{M}$ of some material with similar atomic composition to an equivalent water (or skin) thickness $\mathrm{t}_{\mathrm{w}}$ (in $\mathrm{mg} / \mathrm{cm}^{2}$ ), we write

$$
t_{w}=\eta t_{M}
$$

where the distance scaling factor for a material $\mathrm{M}$ relative to water, $\eta$, is given approximately by the mass stopping power ratio of the material to water $S_{M} / S_{w}$ (ICRU37). Values of $\eta$ obtained with this simple scheme, and used in the calculations that follow, are listed in Table III for several absorber materials. These values are in good agreement with distance scaling factors determined by Cross (CR68) using range ratios instead of stopping power ratios. 


\section{TABLE III. Scaling Factors for Conversion of Material Thickness $t_{M}\left(\mathbf{m g} / \mathrm{cm}^{2}\right)$ to an Equivalent Water Thickness $t_{w}=\eta t_{M}$}

\begin{tabular}{|c|c|c|c|c|c|}
\hline Material & $\mathrm{H}_{2} \mathrm{O}^{2}$ & $\mathrm{LiF}$ & Air & Teflon $^{\mathrm{b}}$ & Mylar $^{\mathrm{c}}$ \\
\hline$\eta$ & 1 & 0.81 & 0.93 & 0.83 & 0.93 \\
\hline
\end{tabular}
a. Or "skin"
b. Polytetrafluoroethylene, $\left(\mathrm{C}_{2} \mathrm{~F}_{4}\right)_{2}$
c. Polyethylene terephthalate, $\left(\mathrm{C}_{10} \mathrm{H}_{8} \mathrm{O}_{4}\right)_{n}$

The Harshaw Model 8805 TLD, in particular chip 3 for beta particles, is used to measure dose. The associated absorbers are shown in Fig. 1 for the TLD in "contact" (including a small air gap) with a DU slab covered with Mylar. These thicknesses are converted to equivalent water or skin thicknesses by using Eq. (4) and the values of $\eta$ in Table III.

\section{Depth-Dose Distributions}

In Fig. 2, the absorbed dose relative to the absorbed dose at $7 \mathrm{mg} / \mathrm{cm}^{2}$ is shown as a function of depth in tissue. Curve $\mathrm{A}$ is for $\mathrm{DU}$ based on extrapolation chamber measurements by Coleman, Hudson, and Plato (CH83) using Mylar absorbers. Depth in Mylar has been converted to equivalent tissue (or water) depths by using $t_{w}=0.93 t_{\text {Myer. }}$. Even though a small slab of DU (10.12 cm $\times 6.27$ $\mathrm{cm} \times 0.21 \mathrm{~cm}$ ) was used, in view of the detector size (approximately $5 \mathrm{~cm}$ diameter) and the thickness of the Mylar absorber ( $\lesssim 0.25 \mathrm{~cm}$ for $\mathrm{t}_{\mathrm{w}}{ }^{\prime} \mathrm{s}$ in Fig. 2$)$ the slab is effectively infinite in lateral extent. A description of the extrapolation chamber and its use for measurements with natural uranium are given in PL79. 


\section{FIG. 2. Relative absorbed dose as a function of depth in water (skin); $D_{\mathrm{S}} \equiv \mathrm{D}\left(7 \mathrm{mg} / \mathrm{cm}^{2}\right)$.}

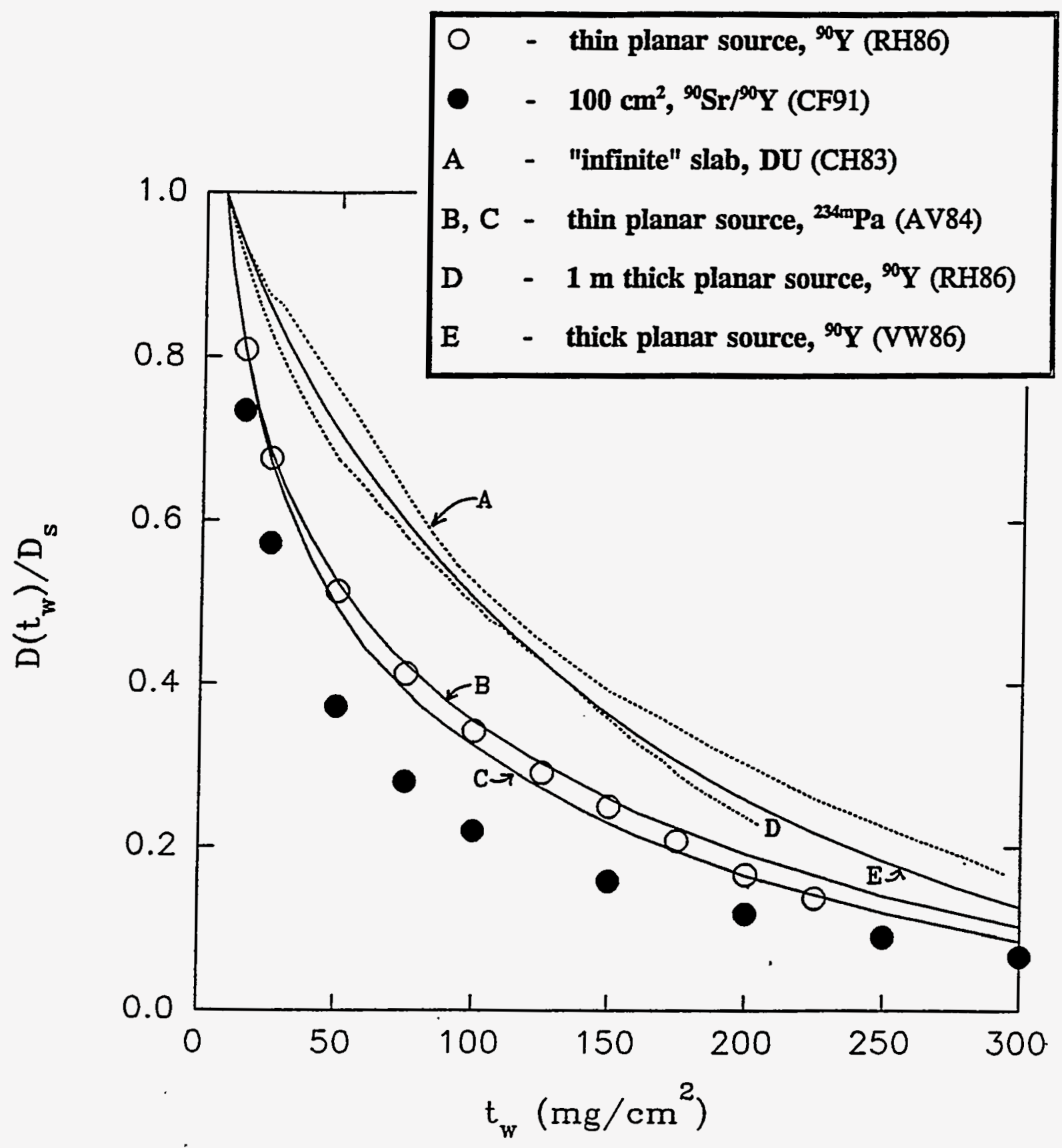


Curves B and C in Fig. 2 show depth-dose calculations for an infinite, thin-plane source of ${ }^{234 m} \mathrm{~Pa}$. The curves were adapted from results in Reference AV84. They are based on analytic functions describing the absorbed dose around point sources in water; a thin planar source configuration was obtained by integration over the source distribution (LO56). Curve B is derived from the work of Loevinger et al. (LO59). Extension and improvement of Loevinger's results by Vynckier and Wambersie (VW82, VW86) lead to slightly lower depth-dose predictions, shown as Curve C.

The open circles are for a thin planar source of ${ }^{90} \mathrm{Y}$ at the interface between a vacuum and a unit-density, tissue-equivalent material based on the Monte Carlo calculations of Rohloff and Heinzelmann (Curve 2, Fig. 1, Ref. RH86). These results are in excellent agreement with curves B and $\mathrm{C}$ and show that, as expected, depth-dose distributions for ${ }^{90} \mathrm{Y}$ and DU have approximately the same shape for the same geometry. This close agreement is exploited in the calculations to follow. The solid circles are from Monte Carlo calculations (CF91) for a 100- $\mathrm{cm}^{2}$, thin circular source of ${ }^{90} \mathrm{Sr}{ }^{00} \mathrm{Y}$. The more rapid falloff of the dose-equivalent ratio with depth, compared with curves $\mathrm{B}$ and $\mathrm{C}$, is due principally to the contribution of the lower-energy beta particles from ${ }^{90} \mathrm{Sr}$ $\left(\mathrm{E}_{\beta}^{\max }=0.54 \mathrm{MeV}\right)$. The ${ }^{90} \mathrm{Sr}$ contribution drops off rapidly with increasing depth and contributes $<2 \%$ to the total dose at $100 \mathrm{mg} / \mathrm{cm}^{2}$.

More relevant for comparison with the measurements on DU (CH83) are depth-dose distributions outside thick sources. Curve $\mathrm{D}$ is for a $1-\mathrm{m}$ thick uniform source of ${ }^{90} \mathrm{Y}$ based on calculations reported in $\mathrm{RH} 86$. Curve $\mathrm{E}$ is calculated for an infinite, thick planar source using the 
analytic formula in VW86 with parameter values for ${ }^{90} \mathrm{Y}$. Both curves agree reasonably well, in terms of shape and magnitude, with the measured values for a DU slab, curve A.

Additional information on the relative decrease in dose rate with distance from the source, or the dose-rate reduction factors, can be found in the literature. Table IV shows values of beta dose (or dose rate) at the face of chip 3 with the TLD in contact with, or $30 \mathrm{~cm}$ in air from, the indicated source. The values for "contact" correspond to a depth $t_{w}=15.5 \mathrm{mg} / \mathrm{cm}^{2}$, accounting for the absorbers covering chip 3 (aluminized Mylar, Teflon, and a small air gap; see Fig. 1); $30 \mathrm{~cm}$ of air adds $t_{w}=33.5 \mathrm{mg} / \mathrm{cm}^{2}$. The dose reduction factor from calculations for a thick, infinite plane source (0.75) agrees reasonably well with that from measurements on DU (0.82). These values are also consistent with the decrease in measured $\dot{\mathrm{L}}_{3}$ 's given in Table $\mathrm{I}$, i.e., 0.79 and 0.78 . For a thin planar source a larger dose reduction is predicted by the smaller factor of 0.65 .

\section{TABLE IV. Reduction in Dose Rates with Distance}

\begin{tabular}{|c|c|c|c|c|}
\hline & $\begin{array}{l}\text { Extrapolation chamber } \\
\text { measurements on DU } \\
\text { (CH83) }\end{array}$ & $\begin{array}{r}\text { Calcule } \\
\text { tissue } \\
\text { (R }\end{array}$ & $\begin{array}{l}90 Y Y \\
\text { gium } \\
\text { gum }\end{array}$ & $\begin{array}{c}\text { Calculation, }{ }^{90} \mathrm{Sr} /{ }^{90} \mathrm{Y} \\
\text { Air } / \mathrm{H}_{2} \mathrm{O} \\
\text { (CF91) }\end{array}$ \\
\hline Source size & thick planar & thick planar & thin planar & $\begin{array}{l}100 \mathrm{~cm}^{2} \text { "thin" } \\
\text { circle, } 1 \mathrm{~Bq} / \mathrm{cm}^{2}\end{array}$ \\
\hline $\begin{array}{l}\text { Quantity measured } \\
\text { or calculated }\end{array}$ & $\dot{\mathbf{D}}(\mathrm{mrad} / \mathrm{h})$ & $\mathbf{H}(\%)$ & $\mathbf{H}(\%)$ & $J^{-}(\mathrm{nGy} / \mathrm{h})$ \\
\hline "Contact" & 190 & 81.6 & 46.1 & 2350 \\
\hline "30 cm air ${ }^{\mathrm{nb}}$ & 155 & 61.2 & 29.8 & 1230 \\
\hline $\begin{array}{l}\text { Dose reduction } \\
\text { factor }\end{array}$ & 0.82 & 0.75 & 0.65 & 0.52 \\
\hline
\end{tabular}

a. The numerical values given are for the quantity measured, or calculated, at the face of chip 3 on the TLD; symbols are those used in the indicated references.

b. "Contact" corresponds to an $\mathrm{H}_{2} \mathrm{O}$ absorber thickness of $15.5 \mathrm{mg} / \mathrm{cm}^{2}$; $" 30 \mathrm{~cm}$ air" adds $33.5 \mathrm{mg} / \mathrm{cm}^{2}$. 
Rohloff and Heinzelmann (RH86) present curves of the relative depth-dose distribution in tissue for ${ }^{90} \mathrm{Y}$ sources for different geometries. The agreement of depth-dose distributions for ${ }^{90} \mathrm{Y}$ and ${ }^{240} \mathrm{~Pa}$ and for thick "slab" sources of ${ }^{90} \mathrm{Y}$ with measurements with $\mathrm{DU}$, noted above in discussion of Fig. 2, supports the use of ${ }^{90} \mathrm{Y}$ to simulate DU. Of particular interest for the present study are the results for an area source in contact with, or $30 \mathrm{~cm}$ from, the absorbing medium and a point source $30 \mathrm{~cm}$ from the absorber. The curves are presented as the percent of dose equivalent at $t_{w}=0$, i.e., $\mathrm{H}_{R}\left(\mathrm{t}_{\mathrm{w}}\right) \equiv 100 \mathrm{H}\left(\mathrm{t}_{\mathrm{w}}\right) / \mathrm{H}(0)$; our function $\mathrm{H}_{\mathrm{R}}$ corresponds to "H(\%)" in RH86. The curves are shown schematically in Fig. 3 with the location of absorbers and chip 3 . The variable $t_{w}$ is measured in units of $\mathrm{mg} / \mathrm{cm}^{2}$. After exposure in a beta-particle field, the light output from chip 3 is proportional to the average dose equivalent in the chip. If we define

$$
\left\langle\mathrm{H}_{R}\right\rangle_{\text {chip }} \equiv \int_{t_{1}}^{t_{2}} H_{R}\left(t_{w}\right) d t_{w} /\left(t_{2}-t_{1}\right)
$$

then the shallow dose equivalent $H_{S}$ is related to the average dose equivalent inferred from the chip, $\overline{\mathrm{H}}$, by

$$
\mathrm{H}_{\mathrm{s}}(\mathrm{mrem})=\frac{\mathrm{H}_{\mathrm{R}}(7)}{\left\langle\mathrm{H}_{\mathrm{R}}\right\rangle_{\text {chip }}} \overline{\mathrm{H}}(\mathrm{mrem})
$$

Here $H_{R}(7)$ is proportional to the dose equivalent at $7 \mathrm{mg} / \mathrm{cm}^{2}, \bar{H}=Q \bar{D}$ where $\bar{D}$ is the average absorbed dose, and $Q=1$ is the quality factor for beta particles. From calibration of the TLDs with ${ }^{137} \mathrm{Cs}$ according to the CEDS procedure (CE93), the light output from chip 3 in terms of the readerspecific, generic unit $\mathrm{mR}^{*}$, given by $L_{3}\left(\mathrm{mR}^{*}\right)$, is related to the average dose equivalent in chip 3 by 
FIG. 3. Relative dose-equivalent distribution $H_{R}$ as a function of depth $t_{w}$ over the chip 3 region of the TLD.

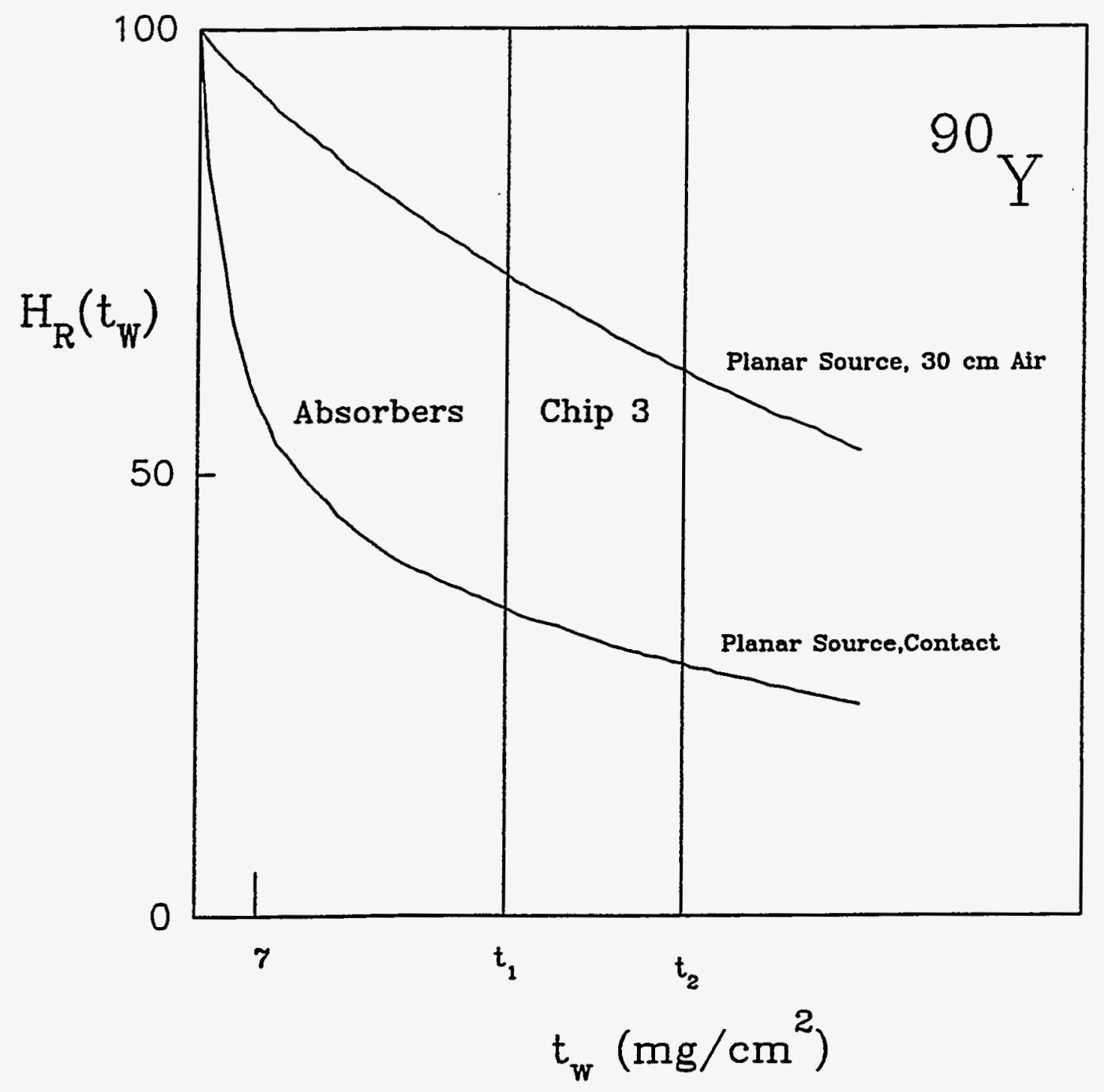




$$
\overline{\mathrm{H}}(\mathrm{mrem})=\frac{10^{3} \frac{\mathrm{mrem}}{\mathrm{rem}}}{976 \frac{\mathrm{mR}^{*}}{\mathrm{rem}}} \cdot \mathrm{L}_{3}\left(\mathrm{mR}^{*}\right)=1.025 \mathrm{~L}_{3}\left(\mathrm{mR}^{*}\right)
$$

The light output from chip 3 is thus related to shallow dose equivalent by

$$
\mathrm{H}_{\mathrm{s}}(\mathrm{mrem})=\mathrm{F}_{\mathrm{s}} \cdot \mathrm{L}_{3}\left(\mathrm{mR}^{*}\right)
$$

with the shallow dose-equivalent calibration factor defined by

$$
\mathrm{F}_{\mathrm{S}}\left(\mathrm{mrem} / \mathrm{mR}^{*}\right) \equiv 1.025 \frac{\mathrm{H}_{\mathrm{R}}(7)}{\left\langle\mathrm{H}_{\mathrm{R}}\right\rangle_{\text {chip }}}
$$

Values of $\mathrm{F}_{\mathrm{z}}$ were calculated from the data in Rohloff and Heinzelmann (RH86) for ${ }^{90} \mathrm{Y}$. Figure 4 shows the change in the shallow dose-equivalent calibration factor with separation (in air) between the TLD chip 3 and thick and thin infinite-plane sources of ${ }^{90} \mathrm{Y}$ (solid curves). In addition, we show values of $\mathrm{F}_{\mathrm{s}}$ calculated for a point source (RH86) and calculated from the data on DU (CH83) (solid dots). The dashed curve is from an analytic formula for a thick, planar source (VW86) with parameter values for ${ }^{90} \mathrm{Y}$. Notice that for distances $\geq 30 \mathrm{~cm}$ the values for $\mathrm{F}_{\mathrm{s}}$ for thick or thin planar sources group in a narrow band around $F_{s} \approx 1.17$. Some of these results are illustrated in Table V for three source/TLD configurations. 
FIG. 4. Shallow dose-equivalent calibration factor $F_{S}$ as a function of depth $x$ in $\mathrm{cm}$ (lower scale) and $t_{w}$ in $\mathrm{mg} / \mathrm{cm}^{2}$ (upper scale) for ${ }^{90} \mathrm{Y}$ and DU sources. Results are derived from data in: Ref. CH83 (solid dots), Ref. RH86 (solid curves), and Ref. Vw86 (dashed

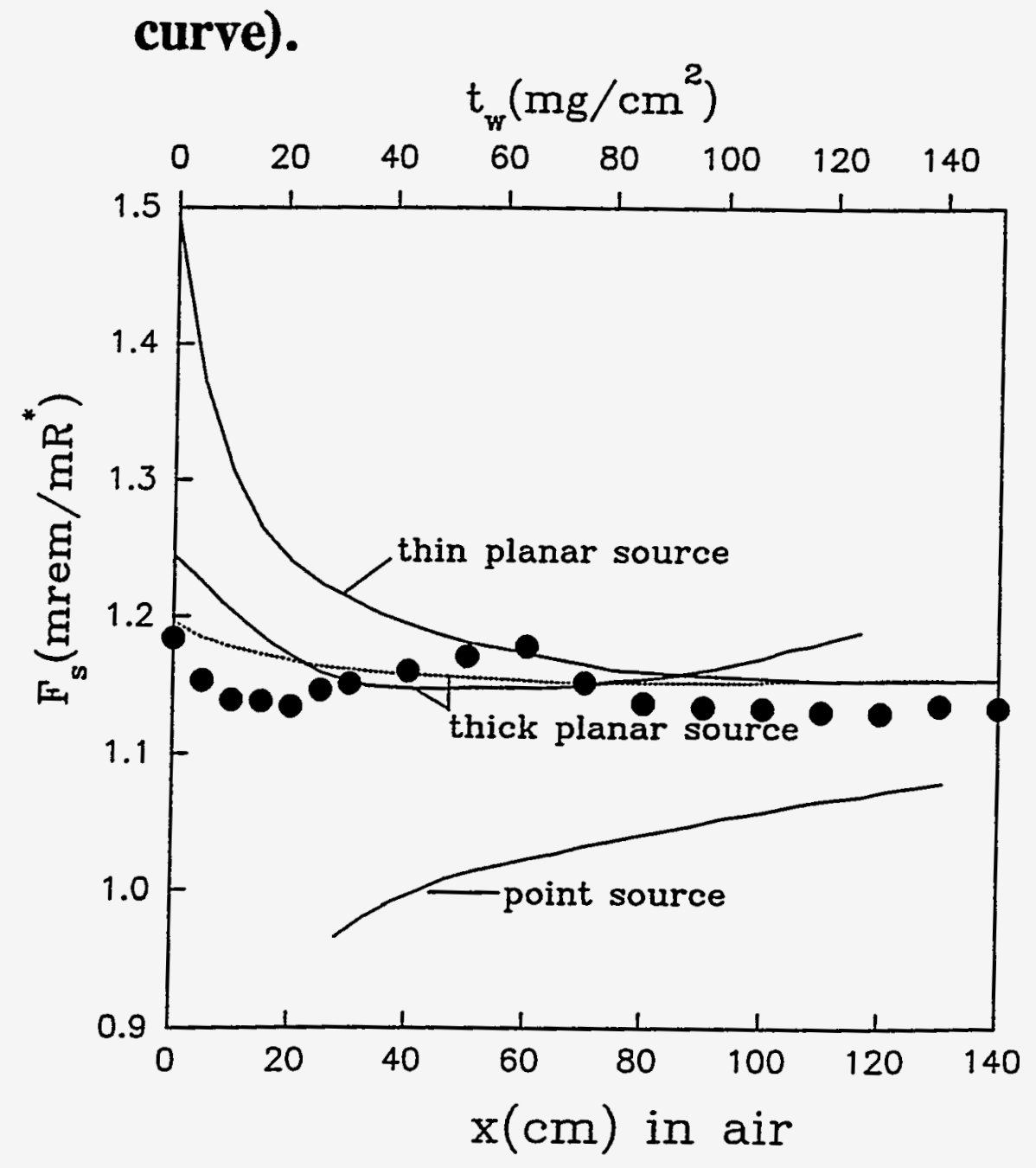




\section{TABLE V. Shallow Dose-Equivalent Calibration Factors (in $\mathrm{mrem} / \mathrm{mR}^{*}$; where $\mathrm{mR}^{*}$ is a facility-specific, repeatable response) for Different Source/TLD Configurations}

\begin{tabular}{|c|c|c|c|c|}
\hline \multirow[t]{2}{*}{ Configuration } & \multicolumn{3}{|c|}{$\begin{array}{c}\left.\mathbf{F}_{\mathbf{3}}{ }^{(0)} \mathbf{Y}\right) \\
\text { (based on calculations in RH86) }\end{array}$} & \multirow{2}{*}{$\begin{array}{l}\text { Reciprocal of shallow dose } \\
\text { equivalent response factor } \\
\text { (based on NIST-traceable calibration) }\end{array}$} \\
\hline & Thin & Thick & Point & \\
\hline Contact with planar source & 1.49 & 1.25 & & $1.68^{\mathrm{a}}$ \\
\hline Planar source $+30 \mathrm{~cm}$ air & 1.21 & 1.16 & & \\
\hline Point source $+30 \mathrm{~cm}$ air & & & 0.97 & $0.96^{\mathrm{b}}$ \\
\hline
\end{tabular}

a. Contact with DU slab

b. Point source ${ }^{90} \mathrm{Sr} /{ }^{90} \mathrm{Y}$; measurements done according to procedures specified in D086 - equivalent to $\sim 30 \mathrm{~cm}$ air

Dosimeter calibrations described in USERS89 and the local ${ }^{137} \mathrm{Cs}$ calibration (CE93) provide values of the shallow dose-equivalent calibration factors for a point source and for contact with a DU slab source. The reciprocals of these quantities are shown in the last two columns of Table V and correspond to results given in Eq. (2a) and Eq. (2b). The other columns correspond to values determined directly from the given reference. The calculated and calibration-derived shallow doseequivalent factors agree quite well for the point source. For the plane sources, the best calibration vs calculation agreement is with the thin, infinite-plane value of 1.49 . However, the more proper comparison is with the thick ("slab") source value of 1.25 which is $26 \%$ less than the calibration- 
derived value of 1.68. As noted above in discussion of Fig. 4 , for distances $>30 \mathrm{~cm}$ the various results for thick or thin planar sources give $\mathrm{F}_{3} \approx 1.17$, a value $30 \%$ less than this 1.68 contact value.

Part of the difference between the calculated and calibration-derived values for contact with a thick slab of DU may be due to the geometry of the chip holder. This is not accounted for in the (one-dimensional) calculations described above. The location of chip 3 in the badge holder suggests that beta particles contributing to energy deposition in the chip should enter the chip in a roughly conical acceptance window with an opening angle of $\sim 60^{\circ}$. If this constraint were incorporated in the theoretical calculations, it would tend to produce smaller values for $\left\langle\mathrm{H}_{\mathrm{R}}\right\rangle_{\text {chip }}$ and hence, according to Eq. (9), increase the theoretical values of the shallow dose-equivalent calibration factor $\mathrm{F}_{\mathrm{s}}$ for an infinite slab. More detailed calculations are required to quantify the size of this increase.

\section{COMPARISONS OF THEORY WITH EXPERIMENT}

Measurements of $\dot{\mathrm{L}}_{3}\left(\mathrm{mR}^{*} / \mathrm{h}\right)$ using TLDs in contact with, or $30 \mathrm{~cm}$ from, an effectivelyinfinite DU slab covered with $7 \mathrm{mg} / \mathrm{cm}^{2}$ Mylar are summarized in Table I. From data in Ref. CH83 we can determine the shallow dose equivalent for these two situations. The dose rate from a DU slab at $7 \mathrm{mg} / \mathrm{cm}^{2}$ Mylar $+7 \mathrm{mg} / \mathrm{cm}^{2}$ skin is $\dot{\mathrm{D}}=193 \mathrm{mrad} / \mathrm{h}$. Thus the measured contact calibration factor is $\dot{\mathrm{H}}_{\mathrm{S}} / \dot{\mathrm{L}}_{3}=1.56 \mathrm{mrem} / \mathrm{mR} *$ (since $\mathrm{H}=\mathrm{QD}$ with $\mathrm{Q}=1$ for beta particles), a value $7 \%$ less than the calibration-derived value of 1.68 .

At $30 \mathrm{~cm}$ (equivalent to $36.2 \mathrm{mg} / \mathrm{cm}^{2}$ Mylar) from the DU slab, $\dot{H}_{\mathrm{s}}=160 \mathrm{mrem} / \mathrm{h}$ follows from Ref. CH83. Using the average of the two $\dot{\mathrm{L}}_{3}$ values in Table I leads to $\mathrm{F}_{\mathbf{3}}=1.64 \mathrm{mrem} / \mathrm{mR}^{*}$, 
in good agreement with the calibration-derived value for contact geometry. This value, and the contact value above, support the theoretical predictions found earlier for the DU slab, as shown in Fig. 4, that $F_{z}$ is approximately constant with distance from the slab. The disagreement in magnitude between the theoretical predictions for $\mathrm{F}_{\mathrm{s}}$ and these experimental values (essentially the same as the calibration-derived value) was noted and discussed in the last section.

\section{CONCLUSIONS AND RECOMMENDATIONS}

Both theoretical calculations (see Fig. 4) and experimental results (Sect. 6) agree that the calibration factor is approximately constant with distance from an "infinite" slab of DU. The difference in magnitude of the predicted and measured calibration factors is due, in part at least, to the TLD acceptance window, which is not incorporated in the theoretical calculations. The experimental results support the value $F_{s}=1.68 \mathrm{mrem} / \mathrm{mR}^{*}$ for the infinite slab. However, our studies indicate that this slab factor is probably conservative for finite sources at a distance from the TLD. Specific electron transport calculations for the dosimeter are needed to extend and refine results presented in this report.

\section{ACKNOWLEDGEMENTS}

We want to thank Johnafred Thomas, Health Physics Department, for a guided tour of the Y-12 Plant and help in describing the processes and activities where workers encounter depleted uranium. Essential experimental help was provided by Kim Sanders, ORNL Radiation Standards and Calibration Laboratory, who was responsible for the preparation and conduct of the TLD-DU measurements. 


\section{APPENDIX: NUMERICAL VALUES FOR CALIBRATION FACTORS}

The shallow dose-equivalent response factor, $r_{s}^{\prime}$, is defined by

$$
\mathbf{r}_{S}^{\prime}\left(\mathrm{mR}^{*} / \mathrm{mrem}\right) \equiv \mathrm{K}_{\mathrm{S}}\left(\mathrm{mR}^{*} / \mathrm{gU}\right) \mathrm{r}_{\mathrm{S}}(\mathrm{gU} / \mathrm{mrem})
$$

In terms of a generic unit $\mathrm{gU}$, the shallow dose-equivalent response factors $r_{s}$ were determined in an initial calibration of the TLD and reader system (MV90, USERS89). The conversion factor, $\mathrm{K}_{\mathrm{s}}$, between $\mathrm{mR}^{*}$ and $\mathrm{gU}$ for chip 3 is based on the experimentally determined factors of $976 \mathrm{mR}^{*} / \mathrm{rem}$ (CE93) and $667.7 \mathrm{gU} / \mathrm{rem}$ (USERS89) through the relation

$$
\mathrm{K}_{\mathrm{s}}=\frac{976 \mathrm{mR}^{*} / \mathrm{rem}}{667.7 \mathrm{gU} / \mathrm{rem}}=1.46 \mathrm{mR}^{*} / \mathrm{gU}
$$

According to CE93, recalibration of the TLD reader system should give values that depart from 976( $\left.\mathrm{mR}^{*} / \mathrm{rem}\right)$ by $\leq 6 \%$. From calibration of the TLDs according to procedures outlined in DO86, the quantity $r_{s}$ is fixed, relative to ${ }^{137} \mathrm{Cs}$, as (USERS89):

DU slab: $r_{s}(g U / r e m)=408.64$

${ }^{90} \mathrm{Sr}{ }^{\rho 0} \mathrm{Y}$ point: $\quad \mathrm{r}_{\mathrm{s}}(\mathrm{gU} / \mathrm{rem})=716.01$

The above values lead directly to Eqs. (2a) and (2b) in the text. 


\section{REFERENCES}

AV84 D. J. Allard, F. J. Vumbaco, A. C. Carpenito, A. J. Saboliauskas, and A. S. Weaver, "Beta Dosimetry Experiences at a Depleted Uranium Metal Fabrication Facility," pp. 509-531 in Proceedings of the International Beta Dosimetry Symposium, Washington, D.C., Feb. 15-18, 1983; Report NUREG/CP-0050 (Jan. 1984).

CE93 Martin Marietta Energy Systems, Inc., Centralized External Dosimetry System - Standard Operating Procedure, CEDS 2-1-10, Rev. 6 (March 31, 1993).

CF91 W. G. Cross, N. O. Freedman, and P. Y. Wong, "Tables of Beta Ray Depth-Dose Distributions from Normally Incident Beams and Skin Contamination," Radiat. Prot. Dosim. 39, 101-104 (1991).

CH83 R. L. Coleman, C. G. Hudson, and P. A. Plato, "Depth-Dose Curves for ${ }^{90} \mathrm{Sr}$ and Natural and Depleted Uranium in Mylar," Health Phys. 44, 395-402 (1983).

CR68 W. G. Cross, "Variation of Beta Dose Attenuation in Different Media," Phys. Med. Biol. 13, 611618 (1968).

D086 Handbook for the Department of Energy Laboratory Accreditation Program for Personnel Dosimetry Systems, DOE/EH-0026 (Dec. 1986). Available from: NTIS, U.S. Department of Commerce, Springfield, VA 22161.

HP88 Health Physics Manual of Good Practices for Uranium Facilities, Report \# DE88-013620 (June 1988). Available from: NTIS, U.S. Dept. of Commerce, Springfield, VA 22161.

ICRU37 Stopping Powers for Electrons and Positrons, ICRU Report 37 (Oct. 1984). Available from: ICRU Publications, 7910 Woodmont Avenue, Bethesda, MD 20814-3094.

ICRU44 Tissue Substitutes in Radiation Dosimetry and Measurement, ICRU Report 44 (Jan. 1989). Available from: ICRU Publications, 7910 Woodmont Avenue, Bethesda, MD 20814-3094.

IR92 Investigation Report - Radiation Exposure Incident at the Paducah Gaseous Diffusion Plant on November 7, 1991, Doc. \# KY/A-561 (Feb. 1992).

KE87 D. C. Kocher and K. F. Eckerman, "Electron Dose-Rate Conversion Factors for External Exposure of the Skin from Uniformly Deposited Activity on the Body Surface," Health Phys. 53, 135-141 (1987).

L056 R. Loevinger, "The Dosimetry of Beta Sources in Tissue: The Point Source Dose Function," Radiology 66, 55-62 (1956). 
LO59 R. Loevinger, E. M. Japha, and G. L. Brownell, "Discrete Radioisotope Sources," Chap. 16 in Radiation Dosimetry, Eds. G. J. Hine and G. L. Brownell (Academic Press, New York, 1956).

MV90 M. Moscovitch, K. J. Velbeck, and G. M. Bencke, "Mixed Field Personnel Dosimetry Using a Nearly Tissue-Equivalent Multi-Element Thermoluminescence Dosemeter," Radiat. Prot. Dosim. 34, 145-148 (1990).

PL79 Phillip Plato, "Absorbed Dose Rate Produced by Natural Uranium as a Function of Depth in Tissue," Intl. J. Appl. Radiat. Isotop. $\underline{30}$, 109-113 (1979).

RH86 F. Rohloff and M. Heinzelmann, "The Influence of Irradiation Geometry on the Response of Different Personal Dosemeters for Beta Dosimetry," Radiat. Prot. Dosim. 14, 141-144 (1986).

USERS89 Dose Calculation Algorithm for the Department of Energy Laboratory Accreditation Program, Engelhard Corporation/Harshaw Crystal and Electronic Products, Solon, Ohio, June 1989.

USERS91 Dose Calculation Algorithm for the Department of Energy Laboratory Accreditation Program User's Manual, Solon Technologies Inc./Harshaw, Solon, Ohio, May 1991.

VW82 S. Vynckier and A. Wambersie, "Dosimetry of Beta Sources in Radiotherapy I. The Beta Point Source Dose Function," Phys. Med. Biol. 27, 1339-1347 (1982).

VW86 S. Vynckier and A. Wambersie, "Dosimetry of Beta Sources in Radiotherapy: Absorbed Dose Distributions Around Plane Sources," Radiat. Prot. Dosim. 14, 169-173 (1986). 


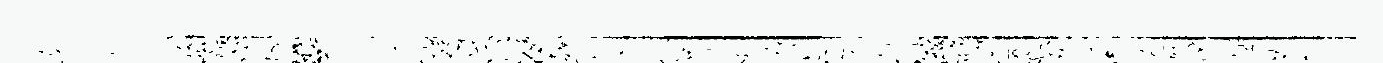




\section{DISTRIBUTION}

1. A. B. Ahmed

2.-4. J. C. Ashley

5. J. H. Barker

6.-8. R. S. Bogard

9. B. G. Bowers

10. S. W. Croslin

11. T. J. Denton

12. G. R. Galloway, Jr.

13. J. B. Hunt

14. K. L. McMahan

15. K. J. Nugent

16. K. L. Reaves

17. K. G. Sanders

18. L. J. Schwanke

19.-23. M. L. Souleyrette

24. J. M. Thomas

25.-27. J. E. Turner

28. Y-12 Central Files

29.-30. A. K. Lee/DOE-OSTI 
